\title{
FROM INTERSEMIOTIC TO INTERTEXTUAL - A HISTORICAL SERENDIPITY
}

Dalibor Kesić, University of Banja Luka, Bosnia and Herzwgovina, dalibor. kesic@flf.unibl.org

10.31902/fll.26.2019.2

UDK 801.73

\begin{abstract}
The term intersemiotic lies at the core of contemporary approaches to semantics, literature, translation and anthropology. At first glance, its connection with text is only intermittent. There is however a blurred area of overlapping in which texts, histories, media and works of art come together to form a dynamic palimpsest of meanings. This paper aims to examine several cases in which momentous works of the past have managed to cross the boundaries of history, nations, languages and media. Their perception and influence have not always been the same, but their common denominator is the power and faculty to exert influence beyond their time and outside their domain. From Shakespeare to Kurosawa and from Cicero to Jerome, forms of art have metamorphosed to accommodate the prevailing beliefs of different eras, condemned in some and glorified in others. Centuries have gone by, but some bygones refuse to be bygones, making one wonder what their secret ingredient is, and to what they owe their everlasting perseverance. The elaboration of this paper shows that in order for a text to be able to endure centuries and to be as topical today as it used to be it the days of yore, it has to be both emphatic with general humanity, and malleable to other media and historical contexts. Just as Galileo gave in to the court of majority and still managed to rewrite the planetary history, so the works of art yield a bit of their own ingenuity every time they undergo an intersemiotic transformation, while at the same time being reborn, revitalized and fit for a new era and a new belief.
\end{abstract}

Keywords: intersemiotic, intertextual, historical, meaning, creed, significance, text, temporal

\section{Introduction}

In today's world, it is difficult for anyone to read a famous book or a poem, to observe a famous painting, drawing or sculpture, to indulge in listening to a famous piece of music or watching a celebrated play or film without being aware of the backgrounds in which the text had been produced, drawn upon, alluded to, burlesqued or satirized. Such frameworks inculcate a primary structure which the reader cannot avoid drawing upon in construing the text. And it is not just today that this phenomenon becomes increasingly conspicuous. Already in 1968 Barthes announced the death of the author and the birth 
of the reader, declaring that a text's unity lies not in its origin but in its destination (148).

Even before Barthes, the notion of originality had its fundamentals shaken. One of the founding texts of semiotics, the Cours de linguistique générale, itself casts a doubtful light on the issue of authorship. Although the text published by Payot in Paris bears the name of Ferdinand de Saussure as its author, it actually was not the work of Saussure at all. He died in 1913 without leaving any thorough sketch of his concepts on general linguistics or semiology. The Cours was first published post-humously in 1916 and was collected by Charles Bally and Albert Sechehaye centering itself upon the notes which had been taken by as many as seven students, together with a few personal notes which had been composed by Saussure himself.

This short reference to the intertextual milestones of the past just serves as a prelude to the contemporary use of intersemiotic transference. In popular culture, intertextuality refers to the incorporation of meanings of one text within another in a reflexive fashion. For example, the television show The Simpsons includes references to films, other television shows, and celebrities. If the reader or the viewer of these references is purposely aware of the people and cultural products being referenced, we delve into the realm of intertextuality, in which the term depicts the shaping of texts' meanings by other texts (Sturken M., \& Cartwright, L.). It can be formulated as an author's borrowing and alteration of a prior text or to a reader's referencing of one text in reading another. Advertisements, as an example of media texts, cannot exist without other discourse types. One can say that it is opportunistic in that it borrows elements from all kinds of genres, and then customs it for its own purposes.

\section{Art in Imitation of Life}

Mystifying the pragmatist notion that art imitates life, intertextuality proposes that art imitates art. Oscar Wilde was the one to take this agenda further, stating defiantly that life imitates art. Texts are influential not only in the assembly of other texts but in the production of experiences too. A significant part of what we know about the world around us stems from what we have read in books, journals and other publications, from what we have seen in the cinema and on television and from what we have heard on the radio. Consequently, life is recreated through texts and molded by texts to a greater degree than we are typically aware of. As Scott Lash observed, "We are living in a society in which our perception is directed almost as often to representations as it is to "'reality'" (Lash 24)Intertextuality can hardly be viewed as a simple extension of a single dimension and there does not seem to be an agreement about what dimensions we should be looking for. Intertextuality is not a story about the text 
alone but of the covenant on the direction of the reading it forges between the author and the reader. As the principal mode of producing texts seems to involve a camouflaging of their debts, reflexivity seems to be an important matter, implying that we ought to consider how marked the particular intertextuality is. Some defining features of intertextuality might include the following:

- reflexivity: how reflexive (or self-conscious) the use of intertextuality seems to be (if reflexivity is important to what it means to be intertextual, then presumably an indistinguishable copy goes beyond being intertextual);

- alteration: the alteration of sources (more noticeable alteration presumably making it more reflexively intertextual);

- explicitness: the specificity and explicitness of reference(s) to other text(s) (e.g. direct quotation, attributed quotation) (is assuming recognition more reflexively intertextual?);

- criticality to comprehension: how important it would be for the reader to recognize the intertextuality involved;

- scale of adoption: the overall scale of allusion/incorporation within the text; and

- structural unboundedness: to what extent the text is presented (or understood) as part of or tied to a larger structure (e.g. as part of a genre, of a series, of a serial, of a magazine, of an exhibition etc.) - factors which are often not under the control of the author of the text. (Chandler 16).

Let us not omit to consider the problem of degrees of intertextuality. Can one deem the most intertextual text to be an indiscernible copy of another text, or does that go beyond the very meaning of intertextuality? Can the most intratextual text be one that undertakes the impossible goal of referring only to itself? This leads to another question and another avenue of the use of genres, argots, idiolects and metalanguages which can hardly be ascribed to any specific inventor. That is why some theoreticians, like Gerard Genette, proposed the term transtextuality as a more inclusive term than intertextuality. He listed five subtypes:

- intertextuality: quotation, plagiarism, allusion;

- paratextuality: the relation between a text and its 'paratext' - that which surrounds the main body of the text - such as titles, headings, prefaces, epigraphs, dedications, acknowledgements, footnotes, illustrations, dust jackets, etc.;

- architextuality: designation of a text as part of a genre or genres (Genette refers to designation by the text itself, but this could also be applied to its framing by readers); 
- metatextuality: explicit or implicit critical commentary of one text on another text (metatextuality can be hard to distinguish from the following category);

- hypotextuality (Genette's term was hypertextuality): the relation between a text and a preceding 'hypotext' - a text or genre on which it is based but which it transforms, modifies, elaborates or extends (including parody, spoof, sequel, translation). (Genette 48)

This list can be further amended with other terms and definitions that include references to other fields of science: cyber hypertextuality referring to text which can take the reader directly to other texts irrespective of their authorship or location. This type of intertextuality distorts the traditional singularity of texts. Reading such texts is akin to palpating routs that ramify in a myriad of directions. This has frequently been used to make commercial messages more ambiguous, as their interpretation and comprehension depends on relating elements in the ad's internal structure to each other, as well as drawing in references from the external world. (Leiss et al. 199).

\section{The Genesis of New Codes}

Claude Lévi-Strauss's metaphorically described the author as a bricoleur who creates improvised structures by appropriating pre-existing materials which are ready-to-hand is now fairly well-known within cultural studies (Lévi-Strauss1964). He observed the creative thought as a kind of bricolage (LéviStrauss 1974, 17): "it builds ideological castles out of the debris of what was once a social discourse" (21): The bricoleur works with signs, constructing new arrangements by adopting existing signifieds as signifiers and speaking through the medium of things by the choices made from limited possibilities (20). "The first aspect of bricolage is [...] to construct a system of paradigms with the fragments of syntagmatic chains," leading in turn to new syntagms (150). Authorship could be seen in similar terms. It would appear that he viewed saw artistic creation as a sort of dichotomy between different elements. Consequently, the practice of bricolage can be seen as operating through several key transformations: addition, deletion, substitution and transposition (Nöth 341).

In other modes of expression such as film, television and the internet, numerous codes have been devised. Christian Metz, a film theoretician, describes codes as not added to one another, or juxtaposed in just any manner; they are organized, articulated in terms of one another in accordance with a certain order, they contract unilateral hierarchies. Thus, a veritable "system of intercodical relations is generated which is itself, in some sort, another code" (242). The dialectical relation between film and its soundtrack can serve as an example of the 
dichotomist essence of their manners of association and shapes of virtual governance. The codes featured in such textual systems obviously cannot be viewed in isolation: the dynamic forms of association between them underwrite the genesis of meaning. Indeed, they should not be understood to always be in a total concord between themselves, for the interaction of codes can be most revealing of inarticulateness, indistinctness, inconsistencies and lapses which may offer the reader a landscape of sundry forms of text interpretation.

The interactions between codes within a genre may change over time, and the growing domination of visuals in advertisements has boosted the uncertainty of meaning interleaved in communication assemblies, as observed by William Leiss and his colleagues:

The growing preponderance of visuals in ads has enhanced the ambiguity of meaning embedded in message structures. Earlier advertising usually states its message quite explicitly through the medium of written text, but starting in the mid-1920s visual representation became more common, and the relationship between text and visual image became complementary - that is, the text explained the visual. In the postwar period, and especially since the early 1960s, the function of text moved away from explaining the visual and towards a more cryptic form, in which text appeared as a kind of 'key' to the visual.

In all, the effect was to make the commercial message more ambiguous; a 'reading' of it depended on relating elements in the ad's internal structure to each other, as well as drawing in references from the external world (199).

The way Barthes used the term relay to describe text/image interactions which were complementary, instancing cartoons, comic strips and narrative film (41) is indicative of this shift. Barthes did not invent a term for the paradoxical case where the image is constructed according to the text (40). One could argue that in the 1950s and early 1960s it was obvious that the spoken text was primary in the correlation between texts and images, in modern society filmic images have gained a greater status in settings such as advertising, so that what he called relay is far more ubiquitous. There are also many situations where the illustrative use of an image offers a niche for equivocal texts. Cognizance of the significance of intertextuality should guide us to inspect the meanings of those imageries and written or spoken text used in close connotation within a text not only in terms of their individual codes, but in terms of their general linguistic arrangement. Evelyn Goldsmith provided a valuable evaluation of practical examination into the connection between related texts and imageries (84).

In the views of Roland Barthes and his description of the concept of anchorage (38) he postulates that linguistic elements can serve to anchor the fa- 
voured interpretations of an image: "to fix the floating chain of signifieds" (39). Barthes brought this concept of textual anchorage up primarily with regards to advertising, but it is equally applicable to other genres too. Barthes claimed that the prime purpose of anchorage was ideological (40). This is particularly apparent when photos are used in milieus such as journals. Photographic subtitles normally exist as impersonal tags for what seemingly exists in the portrayed domain while truly helping express the notions and vistas from which it is to be seen (Chaplin 270). For example, "It is a very common practice for the captions to news photographs to tell us, in words, exactly how the subject's expression ought to be read" (Hall 229). One can take any journal to validate this assertion. However, such verbatim anchorages can possess a more destabilising function. For example, in the 1970s, the photographer Victor Burgin displayed reproductions as an arrangement of pictures taken from press ads together with his own written script that went contrary to the projected connotation of the original advertisements.

While the term intertextuality can typically be used to denote references to other texts, a similar kind of insinuation is what could be referred to as intratextuality - connecting inner relations inside the text. The concept of intertextuality probes the idea of a text having restrictions and questions the dialectics of inside versus outside: where does a text begin and where does it end? The visual and optic media highlight this subject - it is fruitful to consider such media in terms of a notion that Raymond Williams called flow rather than as a sequence of detached texts. One could argue the same about the World Wide Web, where hypertexts' links on a page can connect it straight to many other texts. Texts in any medium, however, can be understood of in analogous positions. The limitations of texts are penetrable. Every text occurs inside an ample network of texts in different varieties and media and no text is an island entire of itself. A handy semiotic procedure is juxtaposition and evaluation of differing processing of similar themes inside or among different types or media.

\section{Medium to Medium and Era to Era Communication}

When Umberto Eco wrote the novel The Name of the Rose not only did he write a literary masterpiece, he also produced a perfect example of intertextuality within a novel. He addresses two kinds of readers through two main characters in the novel who discover a world inside the text by seeing the meaning of symbols, much like an innocent or a meticulous reader outside the text could observe the meaning of the metatext. The narrator of the events is Adso, and he stands for the naive reader. Lettering the story as an aged Benedictine monk, Adso narrates the occasions that happened decades earlier when he was a young apprentice. 
Even though Adso is a keen observer of events, which is a talent that he uses throughout his narration to describe minute details such as the bodily characteristics of the people he encounters and the architectural grandeur of the great abbey, his description is purely an assortment of superficial details with small or no consideration of their inner complexity. Since he does not possess the skill to observe beyond the immediate presentation, Adso is not in a position to comprehend the real meaning of the evidences offered to him. The analytical reader, on the other hand, is embodied in William of Baskerville, a fourteenth-century Franciscan version of Sherlock Holmes. He is directed to different abbeys on sanctioned clerical dealings due to his reputation as an astute viewer of inner complexities of other characters. Adso describes William's talent to infer the truth from facts saying that "He not only knew how to read the great book of nature, but also knew the way monks read the books of Scripture, and how they thought through them. A gift that, as we shall see, was to prove useful to him in the days to follow" (Eco 24-25). He is dispatched to inspect nefarious events a Benedictine abbey.

Upon his arrival, the abbot requests William to explore the bizarre death of one of the priests. During his stay at the abbey, four other priests are murdered. He, eventually pinpoints the killer, who eventually commits suicide. The killer's demise causes a fire, which scorches the great abbey down to ashes. This short synopsis describes the gist of the surface level of the plot. At other, deeper levels, The Name of the Rose is a reflexive recollection of Eco's own hypothesising and a displaying of his idea of the ultimate encyclopaedia of meanings and how meaning is created by connecting and sketching matters of importance through divergent and convoluted ways of reference.

That can be interpreted as Eco's own description of the maze of meanings: "Every path can be connected to every other one. It has no centre, no periphery, no exit, because it is potentially infinite" for it is the space of conjecture (11). Transposition of this is noted throughout academic writings and through the book itself, implying that Eco actually produced a sort of hybrid novel. It is entertaining through the vehicle of assortments ensuing from quotations, elaborate imitations of the historical, philosophical, and contemporary influences that unify the same outlooks on human society. Such a transmission of ideas can only be as successful as far as the reader's in-depth familiarity with these references and their capacity to link them together. When he says "No piece of information is superior to any other. Power lies in having them all on file and then finding the connections. There are always connections; you only have to want to find them" $(24)$, he seems to be joining the dots, some of which exist outside of the novel.

This is only logical taking into consideration that he wrote the book while being deeply interested in intertextuality, which can be seen as further proof 
that he customs chapters in his novels as a sort of self-critical authorial trait for the reader to detect. What is the objective of such a literary flamboyance? It would appear that is it to demonstrate to the reader that he is implying that he does not generate but bestows, borrows, quotes and rearranges layers by taking extracting from another source. This gave rise to some critics, like de Lauretis to question the importance or validity of the book stating that it has no authorial voice and thus no authority of its own, because every description, incident, character, and other device found within it is an objet trouve, something that is to be found first in some other place or work (26). Truth to be told, such a view is overtly imbalanced, bearing in mind that intertextuality is not only important in a full comprehension of The Name of the Rose and the ideas Eco is trying to convey, but also important in for many other novels, since this notion has been preserving for ages in efforts by any author to successfully convey his visions to the audience.

It is true that a rose by any other name would smell as sweet, but this distinctive mixture produced by Eco, if written any other way, would cease to be this particular rose and would metamorphose into something else. One can reasonably argue, therefore, that intertextuality in The Name of the Rose is not only important, it is elementary (the reference to Sherlock not intended) as there is more intertextuality in the novel than just Arthur Conan Doyle, as was just mentioned in the beginning. As a matter of fact, Eco himself says that the character of Adso, who tells the story, was based on the character Zeitblom from Mann's novel, Doctor Faustus (7). Zeitblom, also happens to be the narrator for Doctor Faustus. Anyone with the experience of reading one of these books, upon reading the other would recognize a deeper layer and reminiscence in the character from this narration. This would probably give a solid footing to the statement made by Hutcheon that "for the mystic adept, every word becomes a sign of something else, the truth of what is not said. Therefore, one must learn to read with suspicion, lest something be missed" [8]. This is almost like Eco's mantra when writing The Name of the Rose; every bit of it alludes and refers to something else. The main character is a combination of both a character-type and Doyle's novel that Eco regarded highly - The Hound of the Baskervilles (4). And it is not just the main character that resurrected in The Name of the Rose, Adso is often referred to by William as "my dear Adso" throughout this work. On top of that, upon closer examination of The Hound of the Baskervilles, the same exploratory panache and deduction techniques that are used in The Name of the Rose come to the fore too.

It further entails the dry humour, unclear relationship between Sherlock (William) and Watson (Adso), and even the actual venues, such as the castle and Baskerville Hall, that are replicated almost in every aspect. Spread across the pages of The Name of the Rose, intertextual allusions abound. There are 
also allusions to the philosophical, esoteric and historical issues that were once upon a time discussed by the medievalist scholars. Bearing in mind Eco's enchantment with intertextuality this comes as no surprise, for he had been writing academic works on the topic long before the production of The Name of the Rose, and he continued to do so a way into subsequent years, and also into other novels to follow The Name of the Rose.

This chapter on temporal transmissions from one era to another took the example of Eco's novels to illustrate how complex text references can be, and how many different levels they can operate on. That in turn begs different levels of interpretation, including but not limiting itself to the literary, semiotic, linguistic and philosophic. The postmodern ideology of the irrelevance of the author aside, going back to Roland Barthes's claim of "la mort de l'auteur" (152), Eco's novels yield another level of reading and interpreting that embraces the author's own personal reading experiences. Thus, the author becomes an essential part of the text and is directly involved in the interpretive process.

\section{Eternal Textual Inspirations in Different Contexts}

It is no secret that one of the most undying inspirations in artistic creation in general has had a source in Shakespeare. That was the case during his life, once he departed from this world and it is just as much the case today. How did the old bard accomplish that? Even more striking is the fact that he has managed to bestride the great media divide. It is not just literary works that have drawn lessons and inspiration from his lines, some of the best films ever made have also acknowledged his everlasting impression in them. Arguably, the best Japanese film director ever, and one of the best in the world, Akira Kurosawa, was not shy about his hearty inspirations stemming from Shakespeare's works, King Lear in particular. His 1985 flick Ran opens with four horsemen standing under an awesome landscape of distant mountains, opulent green hillsides below an ample skyline.

They appear as the only discernable impostors on the hillside, only the sporadic shift to a horse's tail giving substance to the group as they press on to loom behind the letters on the screen. They seem minuscule in comparison to the wide background of the wilderness Kurosawa's camera rains before us with an indelible impression. The tranquility of the opening scene is brusquely shattered by the chase of several wild boars. A traditional hunt is in full sway, the interposing camera sequences framing both the frantic attempts of the boars to outrun the leading huntsman, Hidetora on the horseback, his bow bent and the arrow aiming straight. Hidetora's focus, his stable eyes and unrelenting aiming leave no doubt to the spectators that he will successfully kill the boar.

As the watcher immerses in the scene, reminisce of Shakespeare's King Lear begin to loom as it includes numerous reference to hunting. (Goneril: 
"When he returns from hunting/ I will not speak with him", 1.3.7). This serves to remind us that it is a royal sport and to allude to the question of the place of human kind in the natural world, and the instincts directed by animal nature in the deeds of man.

That passage however is rather small, which begs the question why Kurosawa presents the hunt with such a powerful effect at the opening scene of Ran. Hidetora himself is not Shakespeare's Lear. He is an elderly warrior who yearns to justify the carnage he had caused in his fighting days. As the drama unfolds, and just as in Shakespeare's play a gloomy sense begins to incarnate, so the values and firmness of a firmly governed mediaeval world begin to yield and relent to a modern set of gluttonous primacies. An imposition of contemporariness emerges as an inevitability in Ran, where the personal valor and the fighting craft of the samurai gradually get overwhelmed by technologically more effective tools of combat. The samurai archery and swordsmanship are subjugated by muskets, firearms capable of more wide-ranging and unselective devastation.

The reminiscence of Ran in relation to Shakespeare's play is further enhanced by two narrative shifts with somewhat opposing juxtaposition of two sources: the story of the 16th century Japanese father, Mori Motonari, and his three sons and Shakespeare's play that speaks of three daughters. Also, there is Kurosawa's feeling that the characters in the King Lear narrative ought to have a past to clarify their associations within the dramatic progress of the film. In an interview before the New York premiere, Kurosawa insisted that his own dissatisfaction with Shakespeare's King Lear arose from what he saw as a character deficiency in Lear, the absence of any reflection on his past. If he begins in a position of such great power, and then he goes mad because his daughters turn against him, there has to be a reason and the only reason must lie in his past behaviour. He must have been a terrible tyrant to get to where he is at the beginning of the play. And his daughters must have learned from him. There are however views that go contrary - James Goodwin, for example, claims that "A principal consequence of the film's creation of a detailed past of misdeeds by the character is to make Hidetora not only less tragic but also less heroic than Lear" (212).

Janet Adelman (6) sees much of the dramatic power of Shakespeare's King Lear characters in the fact that their existence is not bound by any time reference or geographical designation, and that they are uninhibited by any such triviality or personal history which could potentially alienate their worldly apprehensions from our own. They appear to come from an unidentified part of our innersoles. Kurosawa's idea that his characters and their drives have a preexisting past change the dramatic focus of Ran. The rolling out of the plot has a constant looking back over the shoulders a way back into the past. In King Lear, on the other hand, the focus of dramatic progression, beginning with the king's 
desire for his daughters to formally declare their love for him, lunges forward into the future.

These parallels show how Kurosawa visually arranges the staging of what Shakespeare develops theatrically and verbosely, and when there are noteworthy character differences between the two fathers. Being a warrior lord instead of a king, and having gained power through bellicosity and cruelty instead through devotion, Hidetora is led by a markedly manly sense of what is an apposite behaviour on the part of his sons. Pauline Kael, however, argues that Shakespeare's King Lear is "about primary emotions. Lear stands for every abused parent figure who believed in his children's show of love for him. He is more sinned against than sinning" (354). Another parallel is seen in the scene when Hidetora hands each son an arrow and makes each break it. Then he makes each son try to break, in the same way, a tightly held bundle of arrows.

The elder two play the "game" in the expected fashion, but the youngest, Saburo, points out to the ridiculousness of the test as well as to the delusion of confusing inflexibility with strength by breaking the whole bundle against his knee, and, just as Cordelia, he relinquishes his inheritance and is expelled from the family territory. Christopher Hoile sees the three arrows test as the replacement of the love test in King Lear, even though there are significant differences as it emphasizes the breaking of a bond not between the father and his sons but the bond among the sons themselves (34). Taking into consideration that primogeniture had already been established by the period Kurosawa has chosen, his Lear's silliness appears to be in dividing his kingdom and expecting harmony rather than in expecting the continued love of his children for him.

\section{Conclusion}

In a semiotic perspective, texts are complex signs that consist of signs and their relations to other signs (syntagmatics), their relations to that of which they are signs (semantics), and their relations to their users (pragmatics). Intertextuality is an important aspect of textuality (Heinemann \& Viehweger 76). It is an essential factor for the generation of the meanings of a text in the acts of the production and reception of a text. It opens the internal structure of a text with regard to its relations to other texts. In his Photographic Message, Barthes argues that every reproduction has a denoted message focused on the object being represented and a connoted message constituted by the viewer's culturally informed projections onto the image (17). He concludes that, the connoted message is central (30). When it comes to the relation between text and image, he holds that it ushers in a "parasitic" connoted message rationalizing the image (25). intertextual references assume that the viewer know the people and cultural products being referenced. 
Text-to-text inspiration, in this paper, is epitomized in Eco's view, on the other hand introduces the notion of encyclopedia is a delineation of the cultural knowledge of which the text is a segment. Such an encyclopaedia makes it possible for us to fill in the empty spaces of any given text, which is essential in any act of reading (14). When it comes to the level of the universe of discourse, the ideological structures (14) cause the signs of the text to shape themselves according to the need, in which case the text ought to be read as an autonomous structure. The encyclopaedic notion, on the other hand, requires codified knowledge of a given culture. Text-to-film Akira Kurosawa made some 30 films during his life time. Three of these are generally regarded as belonging in that loose category, Shakespeare films. Steven Spielberg once described Kurosawa as the pictorial Shakespeare of our time and he adapted the Bard for the screen, and into contemporary and period Japanese settings, on three occasions. An intertextual and semiotic way of reading deconstructs all closed readings, for no single reading can actualize all possible intertextual relations. On the other hand, the search for plausible relations with other texts saves intertextual readings from being arbitrary exercises of little importance.

Eventually, all meanings derived from a text are actually a derivation from our cognitive experience. Experiencing a book will vary from one person to another. Likewise, transposition of a text into a visual medium is contingent upon several factors, such as: our previous exposure to the matter and our inclination to interpret it this way or another. Whichever way one opts to view such intertextual interplays, transposition of meaning from one medium to another seems to enhance and enrich its semiotic content.

\section{Works Cited:}

Barthes, R. Image, music, text. New York: Noonday Press, 1977

Chandler, Daniel. Semiotic, the Basics. London and New York: Routedge, 2002

Chaplin, Elizabeth. Sociology and Visual Representation. London: Routledge, 1994

de Lauretis, Teresa. Alice Doesn't: Feminism, Semiotics, Cinema. London: Macmillan,1984

Eco, Umberto. The Name of the Rose. London: Picador/Secker \& Warburg,1984

Genette, Gérard. Palimpsests (trans. Channa Newman \& Claude Doubinsky). Lincoln, NB: University of Nebraska Press, 1997

Goldsmith, Evelyn: Research into Illustrations: An Approach and a Review. Cambridge: Cambridge University Press, 1984

Hall, Stuart. 'The Determinations of News Photographs'. In Cohen \& Young. The Manufacture of News: Social Problems, Deviance and the Mass Media. London: Constable, 1981 
Cook, Guy. The Discourse of Advertising. London: Routledge, 1992

Heinemann, W \& Viehweger, D. Textlinguistik: Eine Einführung. Tübingen, 1991

Hutcheon, Linda. A Theory of Parody: The Teachings of Twentieth-Century Art Forms. New York: Methuen, 1985.

Lash, Scott: Sociology of Postmodernism. London: Routledge, 1990

Leiss, William, Stephen Kline \& Sut Jhally. Social Communication in Advertising:

Persons, Products and Images of Well-Being (2nd Edn.). London: Routledge, 1990

Lévi-Strauss, Claude: Totemism (trans. Rodney Needham). Harmondsworth: Penguin, 1964

Lévi-Strauss, Claude. The Savage Mind. London: Weidenfeld \& Nicolson, 1974

Metz, Christian: Film Language: A Semiotics of the Cinema (trans. Michael Taylor). New York: Oxford University Press, 1974

Saussure, Ferdinand de: Course in General Linguistics (trans. Wade Baskin). London: Fontana/Collins, 1974

Sturken, M., \& Cartwright, L. Practices of Looking: An Introduction to Visual Culture. New York: Oxford University Press, 2001

Hoile, Christopher, "King Lear and Kurosawa's Ran: Splitting, Doubling and Distancing", Pacific Coast Philology, Vol. 22, p 29-33, 1987

Kael, Pauline Deeper into Movies, Boston, Little, Brown, 1973

Goodwin, James. Akira Kurosawa and Intertextual Cinema. Baltimore: Johns Hopkins University Press, 1994

Adelman, Janet (ed.), Twentieth Century Interpretations of King Lear, Prentice Hall, Englewood Cliffs, 1978

\section{OD INTERSEMIOTIČKOG KAO INTERTEKSTUALNOM - ISTORIJSKI SPLET OKOLNOSTI}

Termin intersemiotički leži u srži savremenih pristupa semantici, književnosti, prevođenju i antropologiji. Na prvi pogled, njegova veza sa tekstovima je tek sporadična. Međutim, postoji oblast preklapanja u okviru koje tekstovi, istorije, mediji i umjetničke kreacije spajaju svoje karakteristike u obliku dinamičnog palimpsesta značenja. Ovaj rad teži ka ispitivanju nekoliko oblasti u okviru kojih su značajni radovi iz prošlosti uspjeli da prevaziđu jazove istorije, nacija, jezika i medija. Njihova percepcija i uticaj nisu uvijek bili jednaki, ali njihov zajednički imenitelj je moć i sposobnost uticanja izvan svoje ere i izvan svog domena. Od Šekspira do Kurosave, i od Cicerona do Žeroma, umjetničke forme su prolazile kroz svojevrsnu metamorfozu kako bi udovoljili preovlađujućim vjerovanjima različitih era, pri čemu su u nekima od njih bivali prokazani a nekima glorifikovani. Vijekovi su prošli, ali neke stvari iz prošlosti jednostavno odbijaju da se umirove, 
dovoljno da se čovjek zapita u čemu leži tajna njihove istrajnosti, i čemu duguju vječitu inspirativnost. Elaboracija u ovom radu pokazuje da bilo koji tekst, da bi bio u stanju da traje vijekovima, i da bude aktuelan danas koliko i prije nekoliko vijekova, mora da bude kako empatičan sa opštom ljudskosti, tako i prijemčiv za ostale medije i istorijske kontekste. Isto kao što je i Galileo ustuknuo u sudu većine, a ipak uspio da ispiše planetarnu istoriju, tako i umjetnički radovi, ustupaju dio sopstvene ingenioznosti svaki put kada se podvrgavaju intersemiotičkoj transformaciji, dok u isto vrijeme bivaju iznova rođeni, revitalizovani i spremni za novu eru i novo vjerovanje.

Ključne riječi: intersemiotički, intertekstualni, istorijski, značenje, vjerovanje, značaj, tekst, vremenski. 